Historic, archived document

Do not assume content reflects current scientific knowledge, policies, or practices. 



\title{
Price List of Gladioli
}

\author{
orruke or
}

\section{Wayside Gardens Company Mentor, Ohio}

\section{The Largest Growers of Hardy Plants in America}

\section{CHOICE GLADIOLI}

Within recent years hybridizers have produced some of the very best Gladioli, being noted for their strong, free growth, free-flowering qualities, purity of color and their ability to produce satisfactory results in our climate even under the most ordinary conditions, and whether wanted for show in the garden or for cutting, the sorts offered under this head now hold the premier place in their respective colors and are offered at prices so reasonable, considering their high grade, that they should be planted in quantity wherever summer flowers are wanted.

AMERICA. Conceded to be one of the finest varieties for cutting or bedding ever sent out; color a beautiful soft flesh-pink; orchid-like in its coloring and texture $\$ 0.75 \quad \$ 5.00$

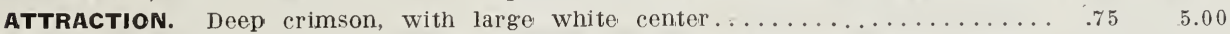

AUGUSTA. Pure white with lavender anthers; strong straight spike often having branches $\ldots \ldots \ldots \ldots \ldots \ldots \ldots \ldots \ldots \ldots \ldots \ldots \ldots \ldots \ldots \ldots \ldots \ldots \ldots \ldots \ldots \ldots \ldots \ldots$ fighter in the

BARON HULOT. Full round flowers of rich velvety purple-violet, lighter in the
throat, a small golden rib throngh the lower petal is contrastingly effective;

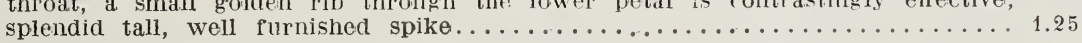

CHICAGO WHITE. Pure white, lightly marked with lavender; fine for cutting..... .75

EMPRESS OF INDIA. Rich velvety dark red with deep shadings. . . . . . . . . 1.00 75 5.00

EVELYN KIRTLAND. A beautiful shade of rosy rink, darker at the edges, fading to shell-pink at the center with brilliant scarlet blotelies on lower petals; the entire flower showing a glistening, sparkling lustre. Very tall spike............ 1.50

OLIATH. Of great value as a garden flower if planted in generous quantity; the mass of dark purplish hlue flowers making a wonderful effect among the pre-

vailing light shades of other Gladioli $\ldots \ldots \ldots \ldots \ldots \ldots \ldots \ldots \ldots \ldots \ldots$
GFETCHEN ZANG. Liberal bloom in that always acceptable shade; soft, melting pink merging into searlet on lower petals...................... 1.00

HALLEY. Delicate salmon-pink, slightly roseate, the lower petals showing creamy blotch bisected by red stripe. One of the earliest to bloom.............

KUNDERDII GLORY. Large creamy white flowers with crimson stripe in center of each petal; end of petals ruffled..................... each.. 1.00

KLONDYKE. Rather dwarf growth, but very desirable as one of the earliest yellows. Pale primrose with crimson maroon blotch on lower petal...........

LILY LEHMANN. A delicate combination of pink and white, unusually large and strong growing for this type. Purest ivory-white flushed pink at tips of petals,

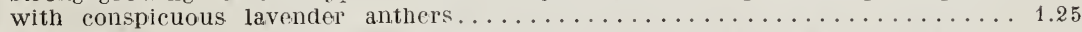

L'IMMACULEE. A pure white variety, having long, slender spikes of a dozen or more well-set blooms, of good substance and dirability $\ldots \ldots \ldots \ldots \ldots \ldots \ldots \ldots \ldots \ldots 1.25$

LOVELINESS. A beautiful cream colored variety of good form and substance; the

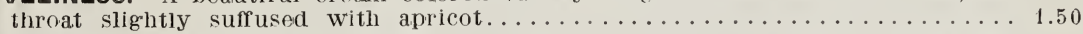

MRS. DR. NORTON. Immense flower, crcamy white overlaid or tinted soft pink, end uf petals showing a charming picotee of defper pink. This has been one of the most notable show varieties of the past fom years. 
MRS. FRANCIS KING. A fine strong growing variety with large spikes of showy flowers. Color a bright shade of pure scarlet.....................

MRS. FRANK PENDLETON, JR. A magniflcent variety which has won various awards. Every bud opens up in water Pully and perfectly. Flawers are very large and well expanded, of a lovely flushed salmon pink; with blood-red blotches in the throat.

MRS. WATT. A most distinct and beautiful sort, of a rich deep cherry-red..... 1.00

NIAGARA. A delightful cream shade blending to canary-yellow . . . . . . . . . . 1.00

PANAMA. An improved America, largest and most notable spike of bloom among all

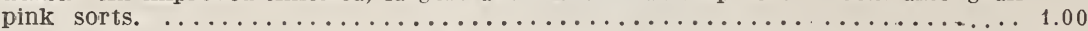

PEACE. Very large, nearly white, with pale violet feathering on lower petals; flowers correctly placed on a tall graceful spike................... 1.00

INK PERFECTION. This magnificent sort is a soft apple-blossom pink with chamois suffusion that is very attractive..............................

RINCE OF WALES. An early flowering sort with fine spikes of large flowers of delicate apricot-pink suffused salmon $\ldots \ldots \ldots \ldots \ldots \ldots \ldots \ldots \ldots \ldots \ldots \ldots \ldots \ldots \ldots \ldots \ldots \ldots$

SCHWABEN. Clear canary yellow, shading to soft sulphur. Largest flower stalk and
leaves of all. Planted 7 or 8 inches apart in rich soil produces wonderful

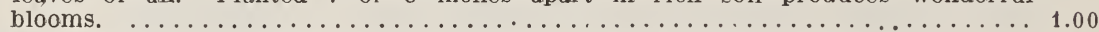

WAR. Deep blood-red, shaded crimson-black. A ieader among the large reds. . . . . 1.25

YELLOW HAMMER. Pure yellow, lightly marked with red in the throat; a beautiful variety for cutting.

\section{PRIMULINUS HYBRIDS}

The range of colors is from the purest and lightest of yellows to deepest orange and from the softest shade of salmon-pink to rich crimson. On account of their slender and graceful habit, delicate colors and peculiar shape of the flowers they are ideal for vases.

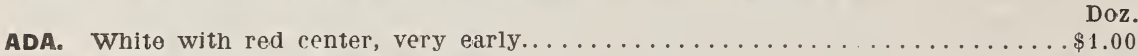

100

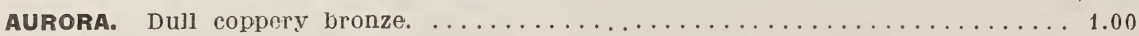

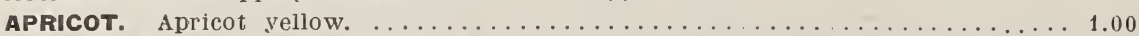

ADORABLE. Blush white with pinkish yellow shading, strong grower. . . . . . 1.00

BUFF BEAUTY. Burnt orange shading to yellow; strong grower very early..... 1.50

Conspicuous. Schwaben yellow, blooms from early to late............. 1.00

DELICATE. Soft pink, center darker pink, outside petals almost white. . . . . . . 1.50

FIRE QUEEN. Orange vermilion flowers with yellow throat.............. 1.00

GLORIOUs. Large apricot pink flowers with a wonderful tint of underlying yellow. 3.50

JULIETTE. Blush white with faint pink markings................. 1.50

$\$ 6.00$

6.00

6.00

6.00

10.00

6.00

10.00

6.00

25.00

KITTIE GRULLEMANS. Large ruffied flowers of a light orange yellow, edge of

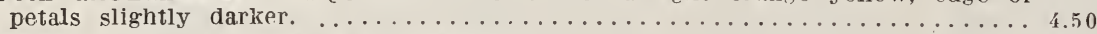

KERENSKY. Fawn colored with creamy center....................

10.00

35.00

LEANDER. Heliotrope blue, very early. This is the nearest to blue of any Gladiolus

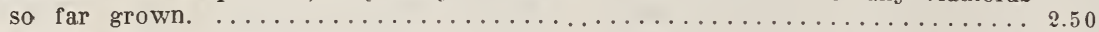

L'UNIQUE. Bronze with orange yellow center; is a wonderfui combination of colors. 1.00

LORD NELSON. Glear buff orange with an underlying pink; tall............. 1.50

MADAM WENTHOLT. Sulphury yellow, strong grower, strong spike.........2.50

ORANGE BRILLIANT. Brilliant orange, flowers of medium size . . . . . . . . . 1.00

PRINCESS ELIZABETH. . Pink, underlaid with a buff orange, clear pink throat.... 2.50

10.07

15.00

6.00

10.00

15.00

6.00

PRINCE OF ORANGE. Orange yellow at outer edge of petals, gradually shading to

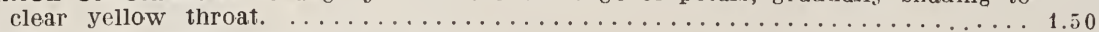

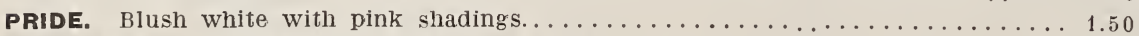

PROSPERITY. Brilliant buff pink, clear pink throat............... 2.50

QUEEN VICTORIA. Glittering bright pink, throat silvery rose............ 1.00

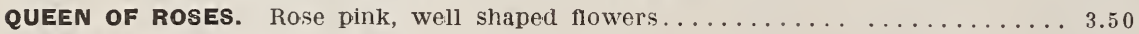

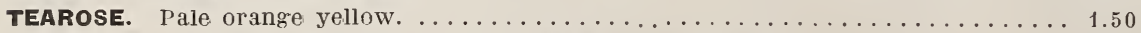

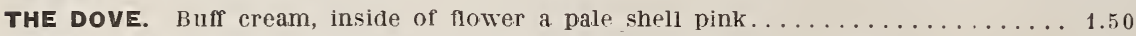

VENUS. Large silvery white flowers with faint blush pink markings......... 3.50

15.00

10.07

10.00

15.00

6.00

25.00

10.00

10.0 !

25.00

MIXED Colors. Choice mixture containing finest shades.............. $1.00 \quad 6.00$

When sold out of first size bulbs measuring $11 / 2$ inches and up we will use second size bulbs measuring $1 \frac{1}{4}$ to $1 \frac{1}{2}$ inches and charge 20 per cent less. Second size bulbs will flower equaljy as well and strong as the first size. 